\title{
LIVESTOCK
}

PRODUCTION

SCIENCE

\section{Carcass quality of 10 beef cattle breeds of the Southwest of Europe in their typical production systems}

\author{
Jesús Piedrafita ${ }^{\mathrm{a}, *}$, Raquel Quintanilla ${ }^{\mathrm{a}}$, Carlos Sañudo ${ }^{\mathrm{b}}$, José-Luis Olleta ${ }^{\mathrm{b}}$, \\ María-Mar Campo ${ }^{\mathrm{b}}$, Begoña Panea ${ }^{\mathrm{b}}$, Gilles Renand ${ }^{\mathrm{c}}$, Françoise Turin ${ }^{\mathrm{d}}$, Sylvie Jabet ${ }^{\mathrm{d}}$,

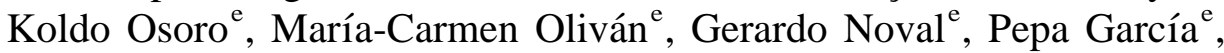 \\ María-Dolores García ${ }^{\mathrm{f}}$, María-Angels Oliver ${ }^{\mathrm{g}}$, Marina Gispert ${ }^{\mathrm{g}}$, Xavier Serra $^{\mathrm{g}}$, \\ Manuel Espejo ${ }^{\mathrm{h}}$, Susana García ${ }^{\mathrm{h}}$, Montaña López ${ }^{\mathrm{h}}$, Mercedes Izquierdo ${ }^{\mathrm{h}}$ \\ ${ }^{a}$ Departament de Ciència Animal i dels Aliments, Universitat Autònoma de Barcelona, 08193 Bellaterra (Barcelona), Spain \\ ${ }^{\mathrm{b}}$ Departamento de Producción Animal y Ciencia de los Alimentos, Universidad de Zaragoza, 50013 Zaragoza, Spain \\ ${ }^{c}$ INRA, Station de Génétique Quantitative et Appliquée, 78352 Jouy en Josas Cedex, France \\ 'Institut de l'Élevage, 14130 Villers Bocage, France \\ ${ }^{\mathrm{e}}$ SERIDA, Apdo 13, 33300 Villaviciosa, Asturias, Spain \\ ${ }^{\mathrm{f}}$ Estación Tecnológica de la Carne, 37770 Guijuelo (Salamanca), Spain \\ ${ }^{\mathrm{g}}$ IRTA, Centre de Tecnologia de la Carn, 17121 Monells (Girona), Spain \\ ${ }^{\mathrm{h}}$ SIA, Apdo 22, 06080 Badajoz, Spain
}

Received 16 October 2001; received in revised form 27 November 2002; accepted 7 January 2003

\begin{abstract}
A sample of about 70 young bulls of each of 10 beef cattle breeds from France and Spain, reared in their typical production systems, was studied regarding growth and carcass quality traits. There were large differences between and within breed-systems. The animals slaughtered in Spain weighed between 444 and $551 \mathrm{~kg}$, whereas the range in France was from 610 to $750 \mathrm{~kg}$. Growth showed a linear tendency; the daily weight gain ranging from 1.03 to $1.65 \mathrm{~kg} / \mathrm{day}$. Asturiana de los Valles and Pirenaica were, among the Spanish populations, the breed-systems with more muscle (around 75\%) and less fat (8-10\%) in the carcass, whereas Avileña-Negra Ibérica, Morucha and Retinta showed opposite characteristics (60-65\% muscle and 17-19\% total fat at the 6th rib). Bruna dels Pirineus and Asturiana de la Montaña occupied an intermediate position. All of the French breed-systems, Aubrac, Gasconne and Salers surpassed $73 \%$ muscle, while the percentage of total fat ranged from 7.6 to $10 \%$. Salers breed-system also showed the longest and thinnest hind-limb. In the wide range of carcass weights studied in this paper, the general relationships among carcass traits were confirmed. Animals with the better conformation were also leaner. Longer carcasses tended to be associated with poor conformation and fatness. Bone content was clearly opposed to carcass conformation and muscle content.
\end{abstract}

(C) 2003 Elsevier Science B.V. All rights reserved.

Keywords: Beef cattle; Breed-system; Carcass composition; Carcass morphology; Phenotypic relationships

*Corresponding author. Tel.: +34-93-581-1399; fax: +34-93-581-2106.

E-mail address: jesus.piedrafita@uab.es (J. Piedrafita). 


\section{Introduction}

According to FAO (1998), the utilisation of appropriate farm animal genetic resources to achieve and maintain sustainable production systems which are capable of responding to human needs is necessary for national and global food security. A first step in the management of these resources includes their identification, description and characterisation. The probability of survival of a population or breed is strongly linked to its ability to meet current and future market demands, in our case, quality meat.

Several experiments were carried out previously to characterise production, carcass and meat quality traits of the Spanish breeds (e.g., Vallejo, 1971; Vallejo et al., 1991; Vallejo et al., 1992). Provided the beef cattle breeds have been submitted to selection programmes and the management and feeding systems have been modified, studies on production, carcass and meat quality characteristics are periodically needed. Recently, Albertí et al. (1995), Santolaria et al. (1997), Sañudo et al. (1998) and Campo et al. (1999) made a comprehensive study on carcass and meat quality traits of seven breeds, six of them involved in this study. Their study, including a total of 24 animals per breed, was aimed at a comparison of the different breeds on standard feeding, rearing place and system, pre slaughter and post slaughter conditions, and with a slaughter weight similar for all breeds (450-470 kg). For the local French breeds, however, this is one the first studies on carcass quality.

The current situation of the market determines local breeds to be produced in restrictive areas, under traditional systems and denominations of origin or quality trade marks. In this context, the objective of this paper is to describe both the between and within breed-production system variability for carcass traits of beef cattle breeds from the Southwest of Europe, each one reared on their typical production systems and slaughtered at their commercial weights. The project was developed on a large sample size (more than 70 animals per breed-production system). The between breed variability represents the joint effect of the genetic differences between breeds and of the production system and their interaction. Within breeds, the observed variability has a genetic component, suggesting the possibilities for within breed genetic selection.

\section{Materials and methods}

\subsection{Animals}

Seven Spanish local beef breeds (Asturiana de la Montaña (AM), Asturiana de los Valles (AV), Avileña-Negra Ibérica (A-NI), Bruna dels Pirineus (BP), Morucha (Mo), Pirenaica (Pi) and Retinta $(\mathrm{Re})$ ), and three French local beef breeds (Aubrac $(\mathrm{Au})$, Gasconne $(\mathrm{Ga})$ and Salers $(\mathrm{Sal})$ ) were studied over two consecutive years. The geographical distribution of the breed-production systems is presented in Fig. 1.

The AV and AM breeds are located in the north of Spain. The first is a double-muscled breed. The AM breed is a small- to medium-sized hardy animal. The $\mathrm{BP}-\mathrm{a}$ meat-type breed which originated from the old Brown Swiss, similar to the American Braunvieh-and $\mathrm{Pi}$ are, respectively, located in the east and central-west parts of the Pyrenees. They are medium to large sized when mature.

The A-NI and Mo breeds are located in Western and Central Spain. The first is medium-sized and the second is small- to medium-sized when mature. The Re breed is found in the west of Spain and is of large size when fully grown. All three are hardy breeds.

The Aubrac and Salers breeds are located in the Centre-South mountain region of France. Both were originally used for draught and milk production. Nowadays, they are dedicated to produce purebred and crossbred weaned calves which are fattened in lowlands or exported. The Gasconne breed is located on the northern side of the Pyrenees mountains and used to produce purebred weaned calves fattened in lowlands.

\subsection{Growth and slaughter conditions}

All animals were entire males, reared under local production systems and slaughtered in their areas of origin in commercial EU-licensed abattoirs. Calves were reared in extensive conditions together with their mother until weaning. Fattening started at about 5-8 months of age in Spain, and the animals were fed ad libitum a breed-specific diet based on concentrated meal and straw or hay. The common characteristic of the concentrate was that both crude protein and energy levels were fairly high (crude protein between 13.8 and 16\%; energy 0.9-1.04 UFV/kg), 


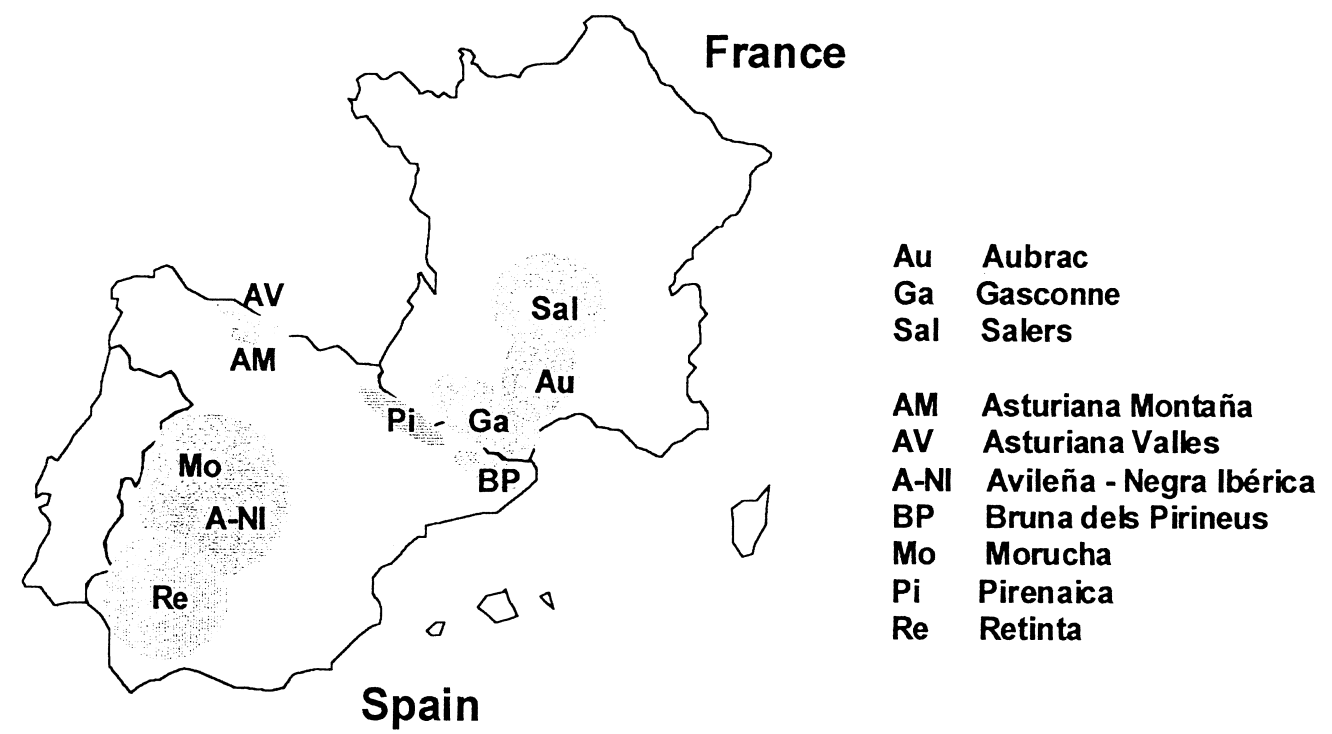

Fig. 1. Geographical distrubution of the breed-systems under study.

and balanced for $\mathrm{Ca}$ and $\mathrm{P}$. The ingredients included mainly products and by-products of cereals (wheat, barley and/or oats) and soybean. Average slaughter weight was breed-specific, depending upon the degree of maturity and local market preferences.

In France, the Ga cattle fattening started when young bulls were about 7 months old, being fattened for 9 months with maize silage ad libitum, complemented with concentrates. Animals of the Sal breed started fattening at $9-10$ months by being fed grass and maize silage ad libitum, complemented with concentrates, for 10 months. Young $\mathrm{Au}$ bulls were reared indoors the first winter after weaning, then reared on pasture the next summer and started fattening at an average age of 19 months. They were fed maize silage and hay ad libitum, complemented with concentrates, for 4-6 months.

\subsection{Carcass evaluation}

Standard carcass evaluation was carried out in all of the animals $45 \mathrm{~min}$ after slaughter, following CEE 390/81, CEE 1208/81, CEE 2930/81 and CEE $1026 / 91$ rules. Several people from each team involved in the study were trained before starting the study for standardising and increasing the precision of measurements. The following variables were recorded:
- Hot carcass weight measured without removing the subcutaneous fat, and maintaining the testicles and kidney and pelvic fat. The tail remained on the right half-carcass.

- Dressing percentage (DP) calculated according to the following formula: (hot carcass weight/ slaughter weight $) \times 100$. Slaughter weight was determined by weighing the animals just before leaving the fattening unit.

- Conformation score (CONF) was graded according to the EUROP classification, with a scale ranging from 15 (very good conformation) to 1 (very bad conformation). The corresponding EUROP grading is as follows: $\mathrm{E}+, \mathrm{E}, \mathrm{E}-$, $\mathrm{U}+, \mathrm{U}, \mathrm{U}-, \mathrm{R}+, \mathrm{R}, \mathrm{R}-, \mathrm{O}+, \mathrm{O}, \mathrm{O}-, \mathrm{P}+$, $\mathrm{P}, \mathrm{P}-$.

- Fatness score (FAT) was measured on a 1-15 scale (1, very low fat; 15 , very high fat). With respect to a $1-5$ classification, the equivalence of the scale used is $1-, 1,1+, 2-, 2,2+, 3-$, $3,3+, 4-, 4,4+, 5-, 5,5+$.

\subsection{Carcass measurements}

Several standard measurements were taken on the left half-carcass, according to the methodology described by De Boer et al. (1974). Variables recorded were carcass length (CL), hind-limb length (HL), 
hind-limb width (HW) and chest internal width (CIW). The degree of maturity was assessed through ossification measurements: number of thoracic epiphyses which were ossified, length of the first thoracic epiphysis ossified process, sternum ossification score (scale 1-7), pre-sternum ossification score (scale 1-4) and sacrum ossification score (scale 15).

Additional variables recorded were kidney knob and channel fat (KKCF), which represents a measure of internal fat expressed as a percentage of carcass weight, and the area of longissimus thoracis or rib eye area (AREA), measured by planimetry on the sixth rib.

\subsection{Tissue and regional composition}

Tissue composition for muscle ( $\mathrm{M} \%)$, bone (B\%), subcutaneous fat $(\mathrm{SF} \%)$, intermuscular fat (IMF\%) and total fat (TF\%) were estimated from the standardised sixth rib, taken at $24 \mathrm{~h}$ post mortem of controlled chilling according to the method described by Robelin and Geay (1975).

\subsection{Statistical analysis}

Means and within year (residual) standard deviations were computed for every breed-production system. The within year (residual) variances were compared for the Spanish and French breeds by means of a Bartlett test.

A multivariate discriminant analysis was performed to evaluate the diversity among the 10 cattle populations. The first three canonical variables which lead to the higher ratio of the between to the within breed variability were computed using the Mahalanobis $D$ distance. These and the rest of the computations have been carried out by means of the SAS package (SAS, 1990). A discriminant function was computed as a classification criterion to assess the capacity of the variables to assign a carcass to its actual breed. Both analyses were performed on the 10 carcass quality traits which were measured on 714 animals (DP, CL, HL, HW, CONF, FAT, SF\%, IMF\%, M\%, and B\%). The correlation of the canonical variables with each of the carcass quality traits and with production traits (fattening daily gain, slaughter age and weight) or the other carcass traits (carcass weight, AREA, KKCF, CIW) were computed.

The within breed-system variability was also studied on variables previously corrected for the effects of breed-system and year since animals were fattened and slaughtered in two annual batches. The within breed variability was therefore studied on the residuals $\left(e_{i j k}\right)$ according to the linear model:

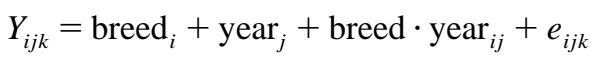

The relationships among variables were estimated on all animals seeking a general biological association between the 10 carcass quality traits mentioned earlier. These relationships were analysed by means of principal component analysis (PCA), which provided synthetic information on the joint variability of different variables of interest. These synthetic factors were correlated to the production traits and other carcass traits as above.

Linear regressions were estimated within each breed-production system between the carcass quality traits and daily weight gain, slaughter weight, and slaughter age as independent variables, although only significant slopes are shown in the tables.

\section{Results and discussion}

\subsection{Between and within breed-production system variability}

\subsubsection{Production traits}

Bulls of different breeds started fattening at different ages and weights (Table 1). Among the Spanish breed-systems, average slaughter weight was between 440 and $510 \mathrm{~kg}$ for AM, AV, A-NI, Mo and $\mathrm{Re}$, whereas BP and Pi animals were slaughtered at higher weights $(550 \mathrm{~kg})$. Among the French breedsystems, bulls from $\mathrm{Au}$ and Sal were slaughtered above $700 \mathrm{~kg}$, whereas the end-point for Ga was 610 $\mathrm{kg}$. Slaughter age was dependent upon the weight at slaughter and growth rate. That age ranged from 12 to 13 months in $\mathrm{A}-\mathrm{NI}, \mathrm{BP}$ and $\mathrm{Pi}$, reaching a higher value for AM (almost 18 months). The bulls of the French $\mathrm{Ga}$ and Sal breeds were also slaughtered at higher ages (16-19 months). The Aubrac production 
Table 1

Performance traits in 10 local beef breed-systems of the Southwest of Europe: means and residual standard deviations

\begin{tabular}{|c|c|c|c|c|c|c|c|c|c|c|}
\hline & $\mathrm{AM}$ & $\mathrm{AV}$ & A-NI & $\mathrm{BP}$ & Mo & $\mathrm{Pi}$ & $\operatorname{Re}$ & $\mathrm{Au}$ & $\mathrm{Ga}$ & Sal \\
\hline Number & 70 & 70 & 71 & 75 & 70 & 55 & 68 & 79 & 82 & 92 \\
\hline On test age (days) & $250.1(32.2)$ & $278.9(22.8)$ & $215.1(28.3)$ & $209.2(27.1)$ & $235.6(28.5)$ & $204.5(40.0)$ & $257.1(38.0)$ & $563.3(20.3)$ & $227.5(23.8)$ & $275.7(24.3)$ \\
\hline On test weight $(\mathrm{kg})$ & $153.5(30.8)$ & $316.9(52.9)$ & $235.4(34.1)$ & $268.1(37.5)$ & $232.8(29.5)$ & $261.3(77.2)$ & $274.7(63.5)$ & $553.1(41.6)$ & $250.0(24.2)$ & $325.3(38.0)$ \\
\hline Slaughter age (days) & $541.0(45.3)$ & $415.7(37.9)$ & $363.6(29.0)$ & $380.6(32.1)$ & $438.9(33.7)$ & $382.7(38.3)$ & $417.7(35.7)$ & $722.8(29.2)$ & $492.3(31.5)$ & $582.1(36.3)$ \\
\hline Slaughter weight $(\mathrm{kg})$ & $443.7(29.0)$ & $509.2(24.1)$ & $481.0(14.8)$ & $541.6(28.2)$ & $458.6(42.0)$ & $551.7(69.0)$ & $498.2(30.3)$ & $753.3(23.4)$ & $610.4(24.6)$ & $714.1(28.4)$ \\
\hline Daily weight gain (kg/day) & $1.03(0.18)$ & $1.41(0.29)$ & $1.64(0.21)$ & $1.63(0.23)$ & $1.11(0.21)$ & $1.65(0.27)$ & $1.41(0.31)$ & $1.25(0.17)$ & $1.37(0.15)$ & $1.29(0.15)$ \\
\hline Carcass weight $(\mathrm{kg})$ & $249.9(21.4)$ & $324.0(21.5)$ & $279.4(9.6)$ & $329.0(19.3)$ & $259.9(25.4)$ & $334.5(44.0)$ & $286.2(17.6)$ & $451.0(16.3)$ & $373.8(17.1)$ & $417.1(19.2)$ \\
\hline
\end{tabular}

Asturiana de la Montaña (AM), Asturiana de los Valles (AV), Avileña-Negra Ibérica (A-NI), Bruna dels Pirineus (BP), Morucha (Mo), Pirenaica (Pi), Retinta (Re), Aubrac $(\mathrm{Au})$, Gasconne $(\mathrm{Ga})$, and Salers (Sal).

Table 2

Carcass measurement traits in 10 local beef breed-systems of the Southwest of Europe: means and residual standard deviations

\begin{tabular}{|c|c|c|c|c|c|c|c|c|c|c|}
\hline & $\mathrm{AM}$ & $\mathrm{AV}$ & A-NI & BP & Mo & $\mathrm{Pi}$ & $\operatorname{Re}$ & $\mathrm{Au}$ & $\mathrm{Ga}$ & Sal \\
\hline Dressing percentage & $56.3(2.2)$ & $63.6(3.1)$ & $58.1(1.5)$ & $60.7(1.5)$ & $57.2(2.1)$ & $60.5(1.6)$ & $57.5(1.9)$ & $59.9(1.8)$ & $61.3(2.2)$ & $58.5(1.6)$ \\
\hline Carcass length $(\mathrm{cm})$ & $121.4(3.4)$ & $123.9(3.6)$ & $126.7(2.8)$ & $126.2(2.8)$ & $125.4(3.6)$ & $126.7(5.8)$ & $131.6(6.0)$ & $139.3(2.4)$ & $132.4(2.7)$ & $138.9(2.9)$ \\
\hline Hind-limb length $(\mathrm{cm})$ & $75.0(1.9)$ & $78.0(2.7)$ & $75.9(4.8)$ & $79.1(2.1)$ & $79.6(2.2)$ & $79.9(4.0)$ & $78.6(4.1)$ & $86.1(1.9)$ & $82.3(1.7)$ & $89.8(1.8)$ \\
\hline Hind-limb thickness $(\mathrm{cm})$ & $22.1(1.5)$ & $26.9(2.4)$ & $27.9(1.8)$ & $30.6(1.4)$ & $29.1(1.5)$ & $29.2(2.2)$ & $29.3(5.3)$ & $32.0(1.1)$ & $29.2(1.2)$ & $29.3(0.9)$ \\
\hline Chest internal width $(\mathrm{cm})$ & $40.2(2.1)$ & $36.4(2.7)$ & $40.9(1.9)$ & $39.2(1.3)$ & $42.6(1.6)$ & $36.4(2.5)$ & $43.1(2.6)$ & $45.6(1.9)$ & $45.7(3.0)$ & $47.3(1.7)$ \\
\hline $\begin{array}{l}\text { Longissimus thoracis } \\
\text { muscle area }\left(\mathrm{cm}^{2}\right)\end{array}$ & $43.4(5.8)$ & $65.0(15.9)$ & $43.9(7.1)$ & $50.5(7.0)$ & $41.9(5.6)$ & $63.6(14.8)$ & $38.9(6.5)$ & $61.0(3.4)$ & $55.1(7.3)$ & $54.9(5.0)$ \\
\hline $\begin{array}{l}\text { Kidney knob and channel } \\
\text { fat }(\%)\end{array}$ & NM & $1.0(0.6)$ & $2.9(0.6)$ & $2.4(0.6)$ & $2.3(0.6)$ & $1.6(0.5)$ & $2.1(0.7)$ & $2.2(0.6)$ & $2.9(0.7)$ & $2.8(0.7)$ \\
\hline Conformation score & $7.5(1.3)$ & $11.8(2.6)$ & $8.5(0.9)$ & $11.2(0.9)$ & $6.0(1.3)$ & $9.9(2.0)$ & $9.4(1.3)$ & $9.5(1.5)$ & $9.5(1.5)$ & $8.3(1.1)$ \\
\hline Fatness score & $6.7(1.2)$ & $4.1(2.2)$ & $8.0(0.9)$ & $6.7(1.5)$ & $8.1(0.6)$ & $5.5(1.7)$ & $8.8(1.2)$ & $7.8(1.4)$ & $8.0(1.0)$ & $8.8(1.6)$ \\
\hline
\end{tabular}

NM, not measured.

Asturiana de la Montaña (AM), Asturiana de los Valles (AV), Avileña-Negra Ibérica (A-NI), Bruna dels Pirineus (BP), Morucha (Mo), Pirenaica (Pi), Retinta (Re), Aubrac (Au), Gasconne (Ga), and Salers (Sal).

Table 3

Tissue composition estimated from the sixth rib of 10 local beef breed-systems of the Southwest of Europe: means and residual standard deviations

\begin{tabular}{|c|c|c|c|c|c|c|c|c|c|c|}
\hline & $\mathrm{AM}$ & AV & A-NI & BP & Mo & $\mathrm{Pi}$ & $\operatorname{Re}$ & $\mathrm{Au}$ & $\mathrm{Ga}$ & Sal \\
\hline Muscle (\%) & $70.0(3.6)$ & $76.0(4.8)$ & $63.9(2.8)$ & $68.2(3.5)$ & $65.9(2.8)$ & $73.0(3.7)$ & $60.5(3.9)$ & $76.1(2.3)$ & $73.9(3.1)$ & $73.4(2.5)$ \\
\hline Bone $(\%)$ & $15.8(2.7)$ & $14.1(2.2)$ & $15.3(2.0)$ & $16.3(2.4)$ & $18.4(2.2)$ & $16.1(1.8)$ & $21.0(3.9)$ & $15.4(1.4)$ & $14.5(1.6)$ & $15.2(1.5)$ \\
\hline Subcutaneous fat (\%) & $1.8(0.7)$ & $1.1(0.7)$ & $4.5(1.3)$ & $3.0(1.0)$ & $3.0(0.8)$ & $1.8(1.1)$ & $3.4(1.4)$ & $1.8(0.6)$ & $2.2(0.8)$ & $1.7(1.0)$ \\
\hline Inter-muscular fat (\%) & $10.6(2.0)$ & $7.3(2.7)$ & $14.2(2.0)$ & $9.7(1.5)$ & $11.0(2.1)$ & $8.1(2.2)$ & $13.6(2.3)$ & $5.8(1.5)$ & $7.8(2.0)$ & $8.3(2.0)$ \\
\hline Total fat $(\%)$ & $12.4(2.5)$ & $8.5(3.3)$ & $18.7(2.2)$ & $12.7(2.1)$ & $14.0(2.4)$ & $9.9(2.9)$ & $17.0(3.1)$ & $7.6(1.7)$ & $10.1(2.3)$ & $10.0(2.4)$ \\
\hline
\end{tabular}

Asturiana de la Montaña (AM), Asturiana de los Valles (AV), Avileña-Negra Ibérica (A-NI), Bruna dels Pirineus (BP), Morucha (Mo), Pirenaica (Pi), Retinta (Re), Aubrac $(\mathrm{Au})$, Gasconne $(\mathrm{Ga})$, and Salers $(\mathrm{Sal})$ 
system was characterised by a particularly high slaughter age (24 months).

Quantitative growth (Fowler, 1968) was assessed through average daily weight gain. There were considerable variations among breed-systems regarding growth rate during fattening. The Spanish breedsystems, fattened on a high-energy diet, can be classified into three main groups. Pi, A-NI and BP showed the highest growth, more than $1.6 \mathrm{~kg}$ per day; $\mathrm{AV}$ and $\mathrm{Re}$ presented an intermediate daily weight gain (1.4 kg/day); and Mo and AM showed the lowest gains (1.11 and $1.03 \mathrm{~kg} /$ day $)$. In comparison with these figures, French breed-systems showed an intermediate to low daily gain, due to the type of diet (maize silage versus concentrate) and the age of fattening. In all breed-systems, the growth during fattening followed a linear pattern. The residual variability expressed as a percentage of the mean (i.e., coefficient of variation) was higher for the Spanish breed-systems than for the French ones. Regarding the first group, the figures ranged from $22 \%(\mathrm{Re})$ to $18 \%(\mathrm{AM})$, whereas the standard deviation for the French breed-systems ranged from 11 to $14 \%$ of the mean.

The results for growth for the Spanish breedssystems were slightly lower than those found by Albertí et al. (1999) in a study comparing all of the breeds in the same fattening conditions, except for A-NI, although the ranking was almost the same. The smaller daily weight gain could be due to the production in more commercial conditions (differences in the diet and management), but also to the differences in the sample of animals studied.

\subsubsection{Carcass quality}

Carcass weight depends upon the decision on slaughter weight and age and also on dressing percentage (carcass yield). $\mathrm{Pi}, \mathrm{BP}$ and $\mathrm{AV}$ reached a high hot carcass weight, around $330 \mathrm{~kg}$, whereas the rest of the Spanish breed-systems presented carcass weight averages ranging between 250 and $285 \mathrm{~kg}$. Two of the French breed-systems ( $\mathrm{Au}$ and $\mathrm{Sal}$ ) exhibited a carcass weight exceeding $400 \mathrm{~kg}$; the carcass weight for the Ga breed was lower.

Three Spanish breed-systems, AV, Pi and BP, surpassed a yield of $60 \%$, AV excelling with a dressing percentage of $63.6 \%$, due to the double muscled condition of several of the young bulls sampled in this breed (Table 2). The rest of the Spanish breed-systems presented a dressing percentage ranging from 56.3 to $58.1 \%$. Among the French breed-systems, the highest dressing percentage corresponded to the Ga breed (61.3\%), the youngest at slaughter, followed by $\mathrm{Au}$ and Sal. In general, the residual variability was low and ranged from 2.5 to $4.9 \%$ of the mean, the differences between breedsystems being significant, both for the Spanish and French breed-systems. The variability of carcass yield was lower-as expected-than the corresponding variability for slaughter weight (Gifford and Stephens, 1979).

Dressing percentage was greater in this study than in the paper of Albertí et al. (1999), probably due to a different definition of the carcass, but also to the fact that in our project the slaughter weight was higher for most of the breed-systems. The ranking, however, was similar. The positive correlation between slaughter weight and carcass yield was previously shown by Andersen (1975), Geay (1978), and Osorio et al. (1995), who found a positive alometry coefficient of this trait, although More O'Ferral et al. (1989) failed to find such a tendency.

The French breed-systems exhibited longer carcasses and hind-limbs, as well as larger chest internal widths than the Spanish ones, in correspondence to their higher slaughter weight (Table 2). It is worth mentioning the great length of $\mathrm{Re}$, Mo and A-NI relative to their weight at slaughter. Also, the more hardy Spanish breed-systems showed a larger chest internal width than the rest. In general, within breedsystem variability was low, ranging from 2 to $6 \%$ of the mean for the Spanish breed-systems, being below $2 \%$ in the French breed-systems. Notwithstanding the differences in slaughter weight, the averages for hind-limb thickness were very similar in the Spanish and French breed systems, with the exception of the AM breed. Variability in this trait was slightly higher than for measures of length, 5-10\%, and around 3-4\% for the Spanish and French breed-systems, respectively.

With respect to the study of Albertí et al. (1999), our results were higher for carcass length and hindlimb thickness. Results for hind-limb length were difficult to compare due to the differences in slaughter weight; however, both studies indicate that the more rustic type breed-systems (Mo, Re and A-NI) 
exhibited longer hind-limbs than BP, Pi and AV beef breeds, when compared at similar weights.

Very large differences between breed-systems were observed for the area of longissimus thoracis muscle. Among the Spanish breed-systems, AV and Pi were above $60 \mathrm{~cm}^{2}$, whereas A-NI, AM, Mo and Re were around $40 \mathrm{~cm}^{2}$. BP and the French breedsystems presented intermediate to high values (51$61 \mathrm{~cm}^{2}$ ). Within breed variability was considerable, ranging from 13 to $25 \%$ in the Spanish breedsystems, the more variable being those of highest average area. The variability in the French breedsystems was lower, ranging from 6 to $13 \%$.

Carcass internal fat (KKCF) included kidney and pelvic fat. The lowest values, expressed as a percentage of hot carcass weight, corresponded to AV and $\mathrm{Pi}$ breed-systems, as is typical in some late maturing beef breeds (Robelin, 1978), whereas the highest ones corresponded to the A-NI and BP breed-systems (2.9 and 2.4\%, respectively). Regarding the French breed-systems, 2.8 and $2.9 \%$ were the averages for $\mathrm{Sal}$ and $\mathrm{Ga}$, respectively. The variability was similar in all breed-production systems, around $0.6-0.7$ percent units.

\subsubsection{Carcass grading}

Average conformation scores exhibited great differences among the Spanish breed-systems but lower for the French breed-systems (Table 2). The EUROP conformation score corresponding to the average of each breed-system was as follows: $\mathrm{AV}, \mathrm{U}+$; $\mathrm{BP}, \mathrm{U}$; $\mathrm{Pi}, \mathrm{Au}$ and $\mathrm{Ga}, \mathrm{U}-$; $\mathrm{A}-\mathrm{NI}$ and $\mathrm{Re}, \mathrm{R}+$; Sal and $\mathrm{AM}$, $\mathrm{R} ; \mathrm{Mo}, \mathrm{O}+$. According to these results, the most conformed breed is $\mathrm{AV}$, related to the double muscled condition of some of its animals, whereas Mo, A-NI and $\mathrm{AM}$ were the least conformed ones. The within breed-system variability of conformation scores was considerable, ranging from 8 to $22 \%$ of the mean for the BP and AV breed-systems, respectively. The higher variability of this last breed could be explained by the existence of a mixture of phenotypically double-muscled and non-double muscled animals in the sample. French breed-systems occupied an intermediate position regarding variability (around 15\%).

For the fatness score, great differences were found both between and within breed-systems. The lower fatness scores corresponded to the AV and Pi breed- systems, whereas A-NI, Mo and Re showed the highest scores, greater than 8 , similarly to the French breed-systems. The residual variability reached very important values for some of the breed-systems, the coefficient of variation ranging from $7 \%$ (Mo) to $54 \%(\mathrm{AV})$. The conformation score measures the thickness of muscle planes and fat in relation to the skeleton size (De Boer et al., 1974) and is related to the muscle/bone ratio and muscle thickness, although correlation estimates are low (Kempster et al., 1982). Furthermore, conformation and fatness scores are subjective measures which will depend upon the scorer's skill. In general, our values for conformation were higher than those of Albertí et al. (1999), except for Mo and Pi breeds. No clear tendency could be observed for fatness, as compared to the study of Albertí et al. (1999). The differences between the results of both projects could be attributed to differences in slaughter ages and weights, as well as in the energy content of the diets.

\subsubsection{Tissue composition}

Tissue composition averages and variability values are presented in Table 3. The specialised beef breedsystems, AV and Pi, showed, as expected, the larger muscle content (76 and $73 \%$, respectively). The French breed-systems showed similar values, followed by $\mathrm{AM}$ and $\mathrm{BP}$, whereas Re, Mo an A-NI showed the lowest values $(60-65 \%)$. Both the between and the within breed-system variability coefficients of the muscle content in the 6th rib were lower than the variability coefficients of the area of the longissimus thoracis muscle. It would suggest that there are more possibilities for selecting rib eye area than total muscle content.

Regarding bone percentage, pronounced differences were observed both between and within breedsystems. AV and the French breed-systems had less bone (14-15\%) than Re and Mo breed-systems (18.4 and $21 \%$, respectively), with the rest of the breedsystems presenting an intermediate position. The differences in bone content may reflect some breedspecific differences and could also be related to differences in carcass weight, since bone content decreases when carcass weight increases (Andersen, 1975; Koch et al., 1979). Variability ranged from 11 to $19 \%$ of the mean in the Spanish breed-systems, with the French breed-systems being intermediate. 
Total fat was the trait presenting the largest variation both between and within breed-systems. Between breed-systems the range surpassed $100 \%$. Whereas $\mathrm{Au}$ and $\mathrm{AV}$ exhibited values of around $8 \%$, $\mathrm{Re}$ and A-NI more than doubled this figure (17 and $18.7 \%$, respectively), with the other breed-systems being intermediate. The within breed variability was in general great, ranging from 12 to $39 \%$, with values inversely correlated to the average value. That wide variability could be due to important differences in age, feeding habits and commercial objectives concerning weight and the fattening state of the carcasses. Furthermore, it is worth mentioning that intermuscular fat percentage was always much larger than the subcutaneous fat content. This last variable, however, exhibited an extremely high variation probably due to difficulties in removing the skin equally during dressing.

Our results were higher for muscle content (except for $\mathrm{Pi}$ ) and lower for fat content (except for A-NI) than those of Albertí et al. (1999) predicted from the 10th rib. This difference is consistent with results of Oliván et al. (2001), who found that in comparison to the 10th rib, the sixth rib provides a better prediction of tissue composition because the 10th rib tends to overestimate the proportion of fat in the carcass.

At the same weight, the late maturing breeds are leaner than the more precocious ones (Fisher, 1990). According to this criterion, our results allows for the classification of the Spanish and French breeds into three groups. AV and Pi and the three French breeds
(Au, Ga, Sal) would belong to the late maturing group, A-NI, Mo and Re, would be early maturing breeds, whereas BP and AM would be of intermediate maturing. These results are similar for the Spanish breeds to those described by French et al. (1969).

\subsubsection{Ossification study}

The degree of ossification recorded in the Spanish breed-systems, related to physiological age, was relatively homogeneous, since the differences were, in general, not important (Table 4). There were almost no completely ossified apophyses, except in the Mo breed. This breed presented the smaller format and is presumably the most precocious one. Average values of sternum or presternum scores indicate greater ossification in the AV, AM and BP breed-systems.

\subsection{Canonical and discriminant analysis of breed- system groups}

The spatial representation of the breed-systems is presented in Fig. 2. The differences between breedsystems were highly significant, as measured by Wilks' $\lambda$. The first canonical axis was mainly determined by carcass size measurements (carcass and hind-limb length), whereas the second axis was determined mainly by the opposition of the proportion of muscle development and carcass compactness to fatness score and the proportion of fat and bone estimated from the sixth rib.

Table 4

Ossification scores in seven Spanish beef cattle breed-systems: means and residual standard deviations

\begin{tabular}{|c|c|c|c|c|c|c|c|}
\hline & $\mathrm{AM}$ & $\mathrm{AV}$ & A-NI & $\mathrm{BP}$ & Mo & $\mathrm{Pi}$ & $\mathrm{Re}$ \\
\hline Number & 70 & 70 & 71 & 75 & 70 & 55 & 68 \\
\hline $\begin{array}{l}\text { Number of ossified } \\
\text { apophyses }\end{array}$ & - & - & $0.8(0.4)$ & $0.0(0.0)$ & $1.0(0.0)$ & $0.0(0.1)$ & $0.0(0.0)$ \\
\hline $\begin{array}{l}\text { First epyphisis ossified } \\
\text { process length }(\mathrm{mm})\end{array}$ & - & - & $20.9(1.2)$ & $20.6(1.2)$ & $21.1(1.5)$ & $20.0(1.4)$ & $21.2(2.0)$ \\
\hline \multicolumn{8}{|l|}{ Ossification score: } \\
\hline Breastbone & $20.2(1.0)$ & $20.2(1.3)$ & $16.8(0.9)$ & $15.9(0.8)$ & $17.9(1.3)$ & - & $17.2(1.9)$ \\
\hline Sternum & $2.2(0.7)$ & $2.1(0.7)$ & $1.0(0.2)$ & $2.3(0.6)$ & $1.0(0.0)$ & $1.6(0.6)$ & $1.4(0.6)$ \\
\hline Presternum & $2.0(0.8)$ & $1.7(0.6)$ & $1.0(0.0)$ & $2.0(0.2)$ & $1.0(0.0)$ & $1.4(0.6)$ & $1.5(0.6)$ \\
\hline Sacrum & - & - & $2.1(0.6)$ & $2.8(0.5)$ & $2.6(1.0)$ & - & $3.5(0.5)$ \\
\hline
\end{tabular}

Asturiana de la Montaña (AM), Asturiana de los Valles (AV), Avileña-Negra Ibérica (A-NI), Bruna dels Pirineus (BP), Morucha (Mo), Pirenaica $(\mathrm{Pi})$ and Retinta (Re). 


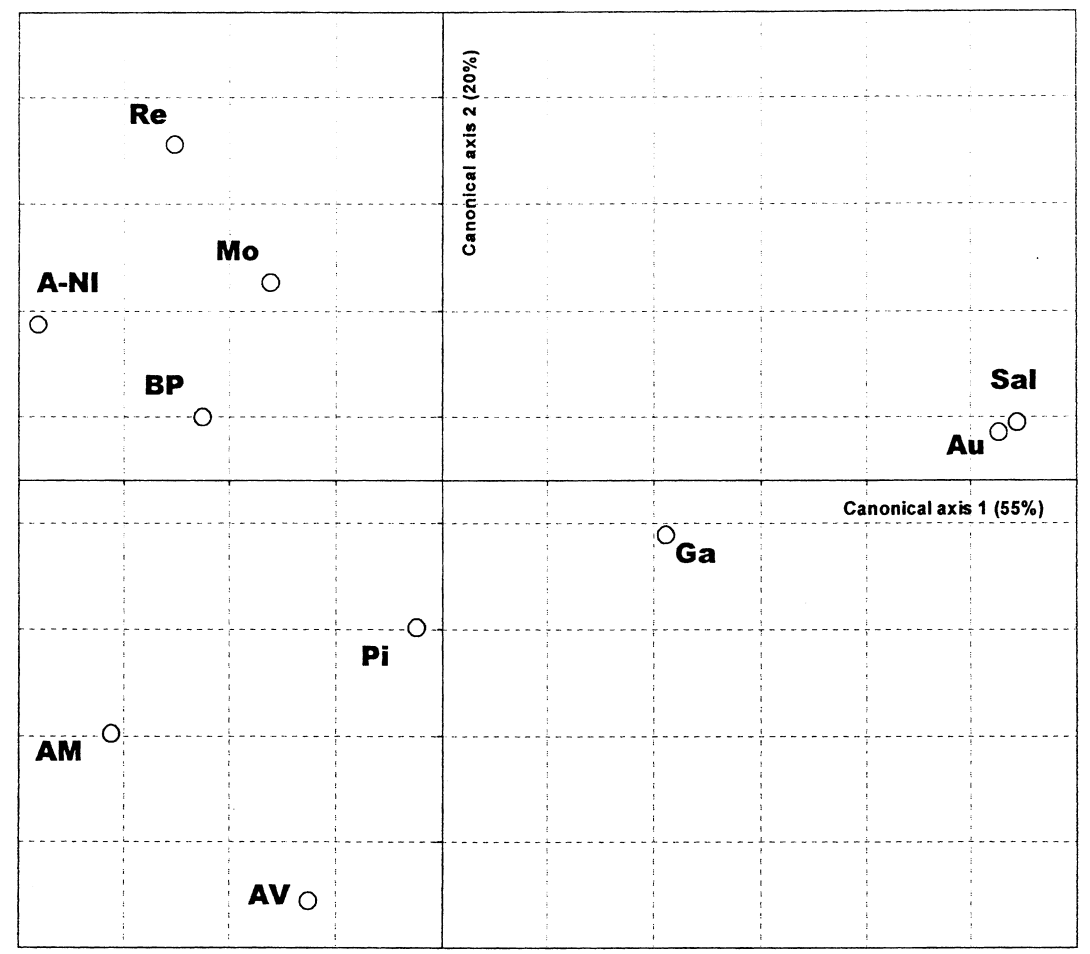

Fig. 2. Canonical representation of Spanish and French beef cattle breed-systems according to carcass quality characteristics. AM, Asturina de la Montaña; A-NI, Avileña-Negra Ibérica; Au, Aubrac; AV, Asturiana de los Valles; BP, Bruna dels Pirineus; Ga, Gasconne; Mo, Morucha; Pi, Pirenaica; Re, Retinta. The first canonical axis represents mainly carcass size, whereas the second axis represents the opposition of muscle development to fatness and the porportion of bone estimated from the sixth rib.

French breed-systems showed the larger sizes, corresponding to higher slaughter weights. AV, AM and Pi breed-systems had more muscle and less fat, whereas A-NI, Mo and Re were on the opposite side. According to this graph, BP and the French breedsystems (Au, Ga and Sal) occupy an intermediate position. The spatial position of the French breedsystems, however, is not consistent with the fact that they ranked very high regarding muscle percent and exhibited very low fat content, and would probably be due to a limited capacity of discrimination of the second canonical axis.

The discriminant analysis provides a different way to look at the differences among breed-systems. Table 5 presents the animals classified correctly into their current groups. The percentage of correctly assigned animals was always above $90 \%$ in the French breed-systems (Au, Ga, Sal) which showed a clear difference between them and the Spanish breeds, mainly due to their particular size, and also due to a reduced within breed-system variability. Regarding the Spanish breed-systems, only two of them (AM and BP) presented a percentage of correctly classified animals above $90 \%$, although three more (AV, A-NI and Mo) allowed us to assign more than $80 \%$ of the young bulls to the breedsystem. Pi, however, was the least well-defined breed-system, since only $60 \%$ of their young bulls could be correctly assigned to it. This could be due to the great variability in slaughter weight of the sample studied.

\subsection{Relationships among carcass characteristics}

The principal component analysis clearly showed sub-clusters of variables which were proximate (Fig. 3). Carcass conformation score and dressing percentage were closely correlated to each other, and also to hind-limb width and muscle percent. They represented the beef conformation quality which was 
Table 5

Number of observations and percent (rounded in parenthesis to the nearest unit) classified into each breed-system ${ }^{\mathrm{a}}$ according to a discriminant function based upon 10 carcass quality traits

\begin{tabular}{|c|c|c|c|c|c|c|c|c|c|c|c|}
\hline & $\mathrm{AM}$ & AV & A-NI & $\mathrm{BP}$ & Mo & $\mathrm{Pi}$ & $\mathrm{Re}$ & $\mathrm{Au}$ & $\mathrm{Ga}$ & Sal & Total \\
\hline $\mathrm{AM}$ & $65(93)$ & $2(3)$ & 0 & 0 & $1(1)$ & $1(1)$ & $1(1)$ & 0 & 0 & 0 & 70 \\
\hline $\mathrm{AV}$ & $5(7)$ & $56(80)$ & 0 & $1(1)$ & 0 & $5(7)$ & $1(1)$ & 0 & $2(3)$ & 0 & 70 \\
\hline A-NI & 0 & 0 & 63 (89) & $1(1)$ & $2(3)$ & 0 & $4(6)$ & 0 & $1(1)$ & 0 & 71 \\
\hline $\mathrm{BP}$ & 0 & 0 & $2(3)$ & $66(90)$ & 0 & $3(4)$ & $1(1)$ & 0 & $1(1)$ & 0 & 73 \\
\hline Mo & $1(1)$ & 0 & $1(1)$ & $1(1)$ & $59(87)$ & 0 & $5(7)$ & 0 & $1(1)$ & 0 & 68 \\
\hline $\mathrm{Pi}$ & $3(6)$ & $5(9)$ & $1(2)$ & $2(4)$ & 0 & $32(60)$ & 0 & 0 & $9(17)$ & $12 \%$ & 53 \\
\hline $\mathrm{Re}$ & 0 & 0 & 7 (10) & $3(4)$ & $2(3)$ & $2(3)$ & $53(79)$ & 0 & 0 & 0 & 67 \\
\hline $\mathrm{Au}$ & 0 & 0 & 0 & 0 & 0 & $1(1)$ & 0 & 72 (92) & $2(3)$ & $34 \%$ & 78 \\
\hline $\mathrm{Ga}$ & 0 & 0 & 0 & $1(1)$ & 0 & 0 & 0 & $1(1)$ & 79 (86) & $11 \%$ & 82 \\
\hline Sal & 0 & 0 & $1(1)$ & 0 & 0 & 0 & 0 & $5(6)$ & $2(2)$ & $74(90)$ & 82 \\
\hline Total & 74 & 63 & 75 & 75 & 64 & 44 & 65 & 78 & 97 & 79 & 714 \\
\hline
\end{tabular}

Asturiana de la Montaña (AM), Asturiana de los Valles (AV), Avileña-Negra Ibérica (A-NI), Bruna dels Pirineus (BP), Morucha (Mo), Pirenaica (Pi), Retinta (Re), Aubrac (Au), Gasconne (Ga), and Salers (Sal).

${ }^{\text {a }}$ Rows include the animals of one breed classified into their own breed-system or into other breed-systems, whereas columns include the animals (own or foreign) classified in the breed-system.

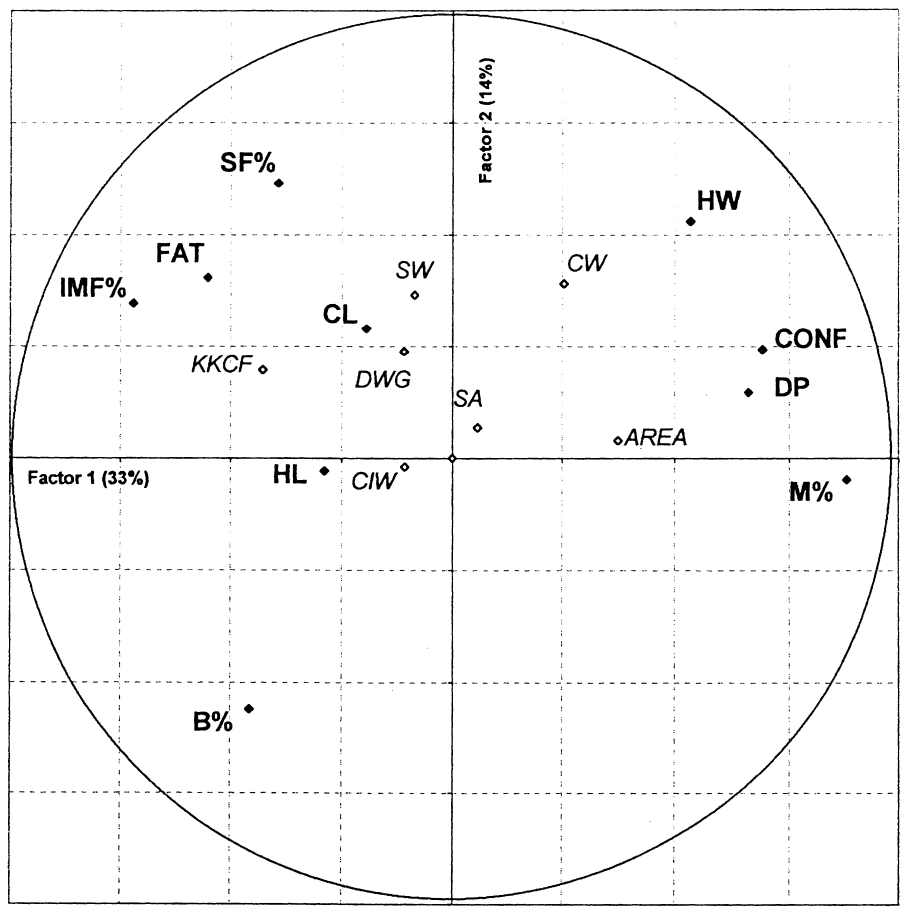

Fig. 3. Factor analysis describing the relationships between carcass quality variables. AREA, area of the longissimus thoracis muscle; B\%, percentage of bone; CIW, chest internal weight; CL, carcass length; DP, dressing percentage; DWG, daily weight gain; FAT, fattening score; HL, hind-limb length; HW, hind limb width; IMF\%, intermusclar fat percent; KKCF, kidney knob and channel fat; M\%, percentage of muscle; SA, slaughter age; SF\%, percentage of subcutaneous fat; SW, slaughter weight. 
opposed to bone percent. The different measures of fatness were grouped and opposed to muscle content at the sixth rib.

The first axis explained $33 \%$ of the total variability of carcass characteristics among animals. It clearly discriminated animals according to their carcass fatness and conformation. There was an opposition between both groups of variables: animals with the better conformation were also the leaner. The second axis explained a lower proportion of the total variability of carcass traits (14\%) and was principally due to variability in bone content. That trait was clearly opposed to carcass conformation and muscle content, although independent of the degree of fatness. It is well accepted that a better carcass conformation is related to lower bone content or a higher muscle/bone coefficient (for review, see Sañudo and Campo, 1997) and lower fat content, especially in double-muscled animals (for reviews, see Ménissier, 1982; Arthur, 1995). Hardy breeds with low adult size, adapted to harsh environments and restricted resources, have relatively large diameters and important fat and bone contents. Similar relationships between muscle, fat and bone have previously been shown by other studies (Kempster and Harrington, 1980; Patterson et al., 1985; Kempster, 1986; Vallejo et al., 1991).

\subsection{Regressions of carcass quality variables on production traits}

Producers have the opportunity to handle several variables which potentially can influence carcass traits. This part of the paper attempts to assess such effects through the regression of carcass variables on daily weight gain (DWG) and slaughter weight.

The average slope in Table 6 represents the general relationships between carcass characteristics and daily weight gain. Regression coefficients for carcass weight were always positive $(P<0.001)$ and ranged from $27(\mathrm{AV})$ to $141(\mathrm{Pi}) \mathrm{kg}$ carcass $/ \mathrm{kg}$ daily gain. Although slaughter weight was theoretically fixed within breed, according to a market demand, animals with higher growth tended to be slaughtered at higher weights whatever the breed. Higher growth was associated with thicker hind-limbs in all breedsystems except AV, and negatively affected dressing percentage, particularly in AV and Ga breed-systems. Those observations are consistent with previous results (Arthur, 1995; Albertí et al., 1997) which

Table 6

Average slope and slopes ${ }^{a}$ for each beef breed-system in the linear regressions relating carcass variables with the daily weight gain (DWG) as the independent variable

\begin{tabular}{|c|c|c|c|c|c|c|c|c|c|c|c|}
\hline & $\begin{array}{l}\text { Average } \\
\text { slope }\end{array}$ & $\mathrm{AM}$ & AV & A-NI & $\mathrm{BP}$ & Mo & $\mathrm{Pi}$ & $\operatorname{Re}$ & $\mathrm{Au}$ & $\mathrm{Ga}$ & Sal \\
\hline Carcass weight & $34 * * *$ & & $-7 * * *$ & & & & $107 * * *$ & & & & $61 *$ \\
\hline Dressing percent & $-1.5 * * *$ & $1.8 * *$ & $-4.5 * * *$ & & & & $1.0 * *$ & & & $-5.5^{* *}$ & \\
\hline Carcass length & $5.0^{* * *}$ & & & & & & $10.0 * *$ & & & & \\
\hline Hind-limb length & $0.8 \mathrm{~ns}$ & & & $-9.0 * * *$ & & & $6.0 * * *$ & & & & \\
\hline Hind-limb thickness & $1.5^{* * *}$ & & $-2.1 * * *$ & & & & $4.2^{*}$ & & & & \\
\hline Chest internal width & $9.7 * * *$ & & $-0.8^{*}$ & & $\mathrm{NC}$ & $0.3^{*}$ & & & & $81.3 * * *$ & \\
\hline L. thoracis area & $0 \mathrm{~ns}$ & & & & & & $11^{+}$ & & & $-26^{*}$ & \\
\hline $\begin{array}{l}\text { Kidney knob and } \\
\text { channel fat }(\%)\end{array}$ & $0.1 \mathrm{~ns}$ & $\mathrm{NC}$ & $0.8^{*}$ & & & & & & & $1.1 *$ & \\
\hline Conformation score & $0.9 * *$ & & $-1.7 * * *$ & & & & & & & & \\
\hline Fatness score & $0.8^{* *}$ & & & & & & & & & & \\
\hline Subcutaneous fat (\%) & $0.3 \mathrm{~ns}$ & & & $-1.1^{*}$ & & & & & & & \\
\hline Intramuscular fat $(\%)$ & $1.0 * *$ & & $2.8^{*}$ & & & & & & & & \\
\hline Muscle $(\%)$ & $-1.5^{*}$ & & $-5.3 * *$ & & & & & & & & \\
\hline Bone $(\%)$ & $0 \mathrm{~ns}$ & & & & & & & & & & \\
\hline
\end{tabular}

ns, not significant; ${ }^{+} P \leq 0.10 ; * P \leq 0.05 ; * * P \leq 0.01 ; * * * P \leq 0.001 ; \mathrm{NC}$, not computed.

Asturiana de la Montaña (AM), Asturiana de los Valles (AV), Avileña-Negra Ibérica (A-NI), Bruna dels Pirineus (BP), Morucha (Mo), Pirenaica (Pi), Retinta (Re), Aubrac (Au), Gasconne (Ga), and Salers (Sal).

${ }^{\text {a }}$ Only slopes significantly different from average are reported. Test of the difference between the breed slope and the average slope. 
demonstrate an inverse relationship between degree of muscularity and growth in double muscled breeds. This property would also explain the association between several measures of tissue composition assessed from the sixth rib and growth in the $\mathrm{AV}$ breed-system.

Slaughter weight did influence, as expected, carcass weight and longitudinal and thickness measurements. For the rest of the variables, the slopes were either not significant or biologically irrelevant when significant (results not shown in tables). That is consistent with previous reports (e.g., Hammond, 1996), since animals tend to increase mainly length and thickness measures, but less so their height after the first year of life.

\section{Conclusions and implications}

Carcasses of 10 beef cattle breed-systems of Southwestern Europe reared in their typical production system have been fully characterised. A great variability was observed among the breedsystems for most of the studied traits and also within breed-system variability for some of them. The variability was, in general, greater within the Spanish breed-systems than in the French ones. Some of the differences in variability could have arisen randomly during the sampling process, for which a higher number of animals and a fattening experiment with all animals in the same conditions would clarify these differences. However, the results of this study are consistent with the fact that the French breeds have been improved by means of selection criteria clearly determined, associated with a better specialisation and adaptation of breed production systems with well defined and well controlled commercial objectives. On the contrary, the greater variability of Spanish breeds could suggest that the improvement programmes, as well as the development of other production factors in order to meet market demands, might be at an initial stage. This variability, however, guarantees that the implementation of improvement programmes could be successful.

A parallelism among the results of this project and the results of the comparison of some of the Spanish breeds in the same fattening conditions and slaughter weight was revealed. In general, the average values of our project were higher. Nevertheless, the main features which distinguish the breeds were maintained in conditions of commercial production and a wide range of slaughter weights.

\section{Acknowledgements}

This research was financed by the EU-FAIR1 CT95 0702 project. The collaboration of several farms, the support of the breed societies and the English revision by Chuck Simmons are greatly acknowledged. Also, the comments and suggestions of an anonymous referee contributed to improving the original manuscript.

\section{References}

Albertí, P., Sañudo, C., Santolaria, P., Lahoz, F., Olleta, J.L., Campo, J.L., 1995. Características de la canal y calidad de la carne de añojos de la raza Retinta. Arch. Zootec. 44, 283-293.

Albertí, P., Sañudo, C., Campo, M.M., Franco, J., Lahoz, F., Olleta, J.L., 1997. Características productivas de terneros de 7 razas bovinas españolas. ITEA (Vol. Extra) 18, 745-747.

Albertí, P., Lahoz, F., Sañudo, C., Olleta, J.L., 1999. Producción y rendimiento de distintas razas españolas. Informaciones Técnicas DGA, no. 68, 8 pp.

Andersen, H.R., 1975. The influence of slaughter weight and level of feeding on growth rate, feed conversion and carcass composition of bulls. Livest. Prod. Sci. 2, 341-355.

Arthur, P.F., 1995. Double muscling in cattle: a review. Aust. J. Agric. Res. 46, 1493-1515.

Campo, M.M., Sañudo, C., Panea, B., Albertí, P., Santolaria, P., 1999. Breed type and ageing effects on sensory characteristics of beef strip loin steaks. Meat Sci. 51, 383-390.

De Boer, H., Dumont, B.L., Pomeroy, R.W., Weniger, J.H., 1974. Manual on E.A.A.P. reference methods for the assessment of carcass characteristics in cattle. Livest. Prod. Sci. 1, 151-164.

FAO, 1998. Primary Guidelines for Development of National Farm Animal Genetic Resources Management Plans. FAO, Rome.

Fisher, A.V., 1990. A review of the factors affecting composition in cattle. In: 41th EAAP Meeting, Toulouse, France, 8-12 July.

French, M.H., Johansson, I., Joshi, N.R., Laughlin, E.H., 1969. Razas europeas de ganado bovino. FAO II, 103-158.

Fowler, V.R., 1968. Body development of some problems and its evaluation. In: Lodge, G.A., Lamming, G.E. (Eds.), Growth and Development of Animals. Butterworths, London.

Geay, Y., 1978. Dressing percentage in relation to weight, sex and breed. In: De Boer, H., Martin, J. (Eds.), Patterns of Growth and Development in Cattle. M. Nijhoff, The Hague, pp. 35-46.

Gifford, D.R., Stephens, P.C., 1979. Growth and carcase charac- 
teristics of Simmental $\times$ Friesian and Friesian $\times$ Friesian cattle in a Mediterranean environment. Aust. J. Exp. Agric. Anim. Husb. 19, 652-657.

Hammond, J., 1996. In: Principios de Explotación Animal. Acribia, Zaragoza.

Kempster, A.J., 1986. Estimation of the carcass composition of different cattle breeds and crosses from conformation assessments adjusted for fatness. J. Agric. Sci. 106, 239-254.

Kempster, A.J., Cuthberson, A., Harrington, G., 1982. The relationship between conformation and the yield and distribution of lean meat in the carcasses of British pigs, cattle and sheep: a review. Meat Sci. 6, 37-53.

Kempster, A.J., Harrington, G., 1980. The value of fat corrected conformation as an indicator of beef carcass composition within and between breeds. Livest. Prod. Sci. 7, 361-372.

Koch, R.M., Dikerman, M.E., Lipsey, R.J., Allen, D.M., Crouse, J.D., 1979. Characterization of biological types of cattle-Cycle II: III. Carcass composition, quality and palatability. J. Anim. Sci. 49, 448-460.

Ménissier, F., 1982. General survey of the effect of double muscling on cattle performance. Curr. Top. Vet. Med. Anim. Sci. 16, 23-53.

More O'Ferral, G.J., Joseph, R.L., Tarrant, P.V., McGloughlin, P., 1989. Phenotypic and genetic parameters of carcass and meat quality traits in cattle. Livest. Prod. Sci. 21, 35-47.

Osorio, J.C., Jardim, P., Guerreiro, J., Siewerdt, F., 1995. Desenvolvimento dos cortes da carcaça em bovinos Hereford. Rev. Bras. AgroCi. 1, 43-47.

Oliván, M., Martínez, A., García, P., Noval, G., Osoro, K., 2001. Estimation of the carcass composition of yearling bulls of "Asturiana de los Valles" breed from the dissection of a rib joint. Meat Sci. 57, 185-190.

Patterson, D.L., Price, M.A., Berg, R.T., 1985. Patterns of muscle, bone and fat accretion in three biological types of feedlot bulls fed three dietary energy levels. Can. J. Anim. Sci. 65, 351361.

Robelin, J., 1978. Répartition des dépóts adipeux chez les bovins selon l'état d'engraissement, le sexe et la race. Bull. Tech. CRZV Theix INRA 34, 31-34.

Robelin, J., Geay, Y., 1975. Estimation de la composition de la carcasse des taurillons partir de la composition de la 6éme côte. Bull. Tech. CRZV Theix INRA 22, 41-43.

Santolaria, P., Sañudo, C., Albertí, P., Campo, M.M., 1997. Estudio de la calidad organoléptica de la carne de añojo de siete razas españolas mediante una prueba de consumidores. ITEA 93 (2), 89-97.

Sañudo, C., Campo, M.M., 1997. Calidad de la canal por tipos. In: Buxadé, C. (Ed.), Vacuno de Carne: Aspectos Claves. Mundi Prensa, Madrid, pp. 465-492.

Sañudo, C., Albertí, P., Campo, M.M., Olleta, J.L., Panea, B., 1998. Calidad instrumental de la carne en siete razas españolas. Arch. Zootec. 48, 397-402.

SAS, 1990. SAS Institute Inc., Cary, NC, USA.

Vallejo, M., 1971. Estudio de la conformación, rendimiento y calidades carniceras en siete razas bovinas españolas. Tesis Doctoral. Universidad de Zaragoza.

Vallejo, M., Alonso, L., Revuelta, J.R., Cima, M., Cañón, J., 1991. Características de las canales de las razas bovinas Asturianas. I. Bases cuantitativas de la valoración subjetiva. Arch. Zootec. 40, 335-357.

Vallejo, M., Gutiérrez, J.P., Cima, M., Cañón, J., Alonso, L., Revuelta, J.R., Goyache, F., 1992. Características de las canales de las razas bovinas Asturianas. II. Valoración cuantitativa y predicción de la composición tisular de canales en la raza Asturiana de los Valles. Arch. Zootec. 42, 29-40. 